\title{
Understanding Extreme Climatic Events for Economic Development in Kenya
}

\author{
Julius M. Huho ${ }^{1}$ and Rose C. Kosonei ${ }^{2}$ \\ ${ }^{1}$ Karatina University, Department of Tourism and Hospitality Management, P.O. Box 1957 Karatina, KENYA \\ ${ }^{2}$ Maseno University, Department of Environmental Studies, P.O. box 333 Maseno, KENYA
}

\begin{abstract}
Kenya is an agri-based economy that heavily relies on rainfall performance. Unfortunately, changes in rainfall patterns have threatened the agricultural sector since it is largely rain-fed. The frequent occurrence and increased severity of climatic extremes, particularly droughts and floods, have led to slow economic development in the affected areas. However, the impacts on the economy vary from one hydrometeorological disaster to the other depending on their characteristics. From the case studies of Laikipia and Bunyala subcounties in Kenya, the study established an increasing trend in both the frequency and magnitude of floods and droughts. Prolonged and severe flood and drought events had adverse impacts on economic development through (a) decrease in agricultural production, (b) poor prices for livestock and agricultural produce and (c) destruction of the immediate environment which in turn exacerbate the impacts. An inverse relationship between economic development and the magnitude of the disaster was established. The consequence have been increased poverty levels in the areas due to slow economic development.
\end{abstract}

Keywords: Extreme climatic events, Floods, droughts, Bunyala, Laikipia North

\section{Introduction}

While agriculture accounts for only $3.2 \%$ of the world's Gross Domestic Product (GDP), it accounts for $30-40 \%$ of the Africa's total GDP. It is the main driver of Africa's economy providing a source of livelihood to $65 \%$ of the population. Despite its critical role in economic development, over $90 \%$ of agriculture in Africa is small-scale and largely rain-fed. For instance, more than $95 \%$ of the farmed land in the Sub-Saharan Africa is rain-fed (Wani, et al., 2009) making it susceptible to climate vagaries. With two-thirds of Africa having semi-arid to arid climates, extreme climatic events, notably droughts and unusually heavy rainfall that cause floods are common phenomena. Droughts occur when there is deficiency in precipitation over extended periods of time causing human suffering to about $60 \%$ of the world's population (Ngaira, 2004). Since 1960s each drought episode in Africa has been more severe than the previous one (Wang'ati, 1996) causing humanitarian crisis in the continent. According to Ayoti (2008) droughts accounted for $20 \%$ of all the natural disasters that occurred between 1970 and 2006 affecting over 80\% of the population in Africa. The droughts of 1970 and 1980 decades pushed the Sahara desert south destroying farmland in Nigeria, Niger and Mali (Alleyne, 2009). Severe food shortages were experienced in Niger, Sudan, Ethiopia, Kenya and Mozambique while additional 17 other African countries experienced inadequate food supplies (Farmer and Wigley, 1985). One of the worst humanitarian crisis caused by an extreme drought occurred in 2011 in the Horn of Africa (HOA) where over 13 million people were in dire need of humanitarian assistance (Action Aid, 2011).

On the other hand, floods occur when total precipitation exceeds evapo-transipration, surface run off and infiltration of water into the ground creating water surplus inundating the earth's surface. Unlike droughts which have slow onset and may persists for long, floods are short lived but more disastrous. Between 1947 and 1980 floods ranked third in severity after tropical cyclone and earthquakes leading to loss of lives (Houghton, 1977). Unfortunately, flood hazards have been increasing in magnitude with number of people affected increasing much more rapidly than those suffering from droughts worldwide (Drought Management Centre (DMC), 2004).Increase in magnitude and frequency of the floods have been observed in Poland, Japan, Germany and Kenya (Pinter, 2010). There have been remarkable floods in the last half of the twentieth century (Ngaira, 1999). The period between 1980 and 1985 experienced more than 160 major floods in Asia causing damage estimated at US\$ 2 billion (Houghton, 1997). In South America, North America, south Asia and Africa floods and mudslides make regular news. In North America, for example, floods and mudslides are the leading cause of deaths from natural disasters. The number of deaths associated with floods increased from 5.2 million per year in 1960s to 15.4 million per year in 1970s in South America. In India, the number of lives lost was fourteen times greater in 1980s compared to 1950s (Clerke, 1991; Cohen and Miller, 2001). In economic terms, floods are the most expensive natural disaster. In Australia, for example, directs costs associated with floods averaged at US $\$ 370$ million per year between 1967 and 2005 (http://www.chiefscientist.qld.gov.au/publications/understanding-floods/consequences.aspx, 2013). 


\section{Climate extremes in Kenya}

Over $80 \%$ of the Kenya landmass falls under arid and semi-arid climates where droughts and floods are the main characteristics of rainfall. This makes Kenya prone to climate vagaries. Evidence of climate change has become more pronounced in through the alternating cycles of droughts and floods. Such cycles have been experienced in Kenya in 2004, 2006 and 2009 where droughts were interposed with floods (Kenya Red Cross Society [KRCS], 2012). As a result, climate related disasters accounts for over $70 \%$ of all disasters in Kenya.

Droughts and floods are not new phenomena in Kenya with their characteristics -intensity, duration and spatial extent - varying from one event to the other. The frequency of occurrence and severity of floods and droughts have been increasing over time. For instance, the frequency of drought increased from once in every 10 years in 1970s, to once in every 5 years in 1980s, once in every 2-3 years in 1990s and every year since 2000 (Howden, 2009). The regular occurrence of floods and droughts has continuously undermined economic development in the affected areas exacerbating poverty levels. The alternating cycles of droughts and floods do not only destroy the livelihood sources but also severely undermined the resilience of the people living in the affected areas (KRCS, 2012). In some arid and semi-arid counties, pastoralists have lost more than half of their livestock to droughts in the past ten years with over $60 \%$ of the inhabitants living below the poverty line (Grünewald et al, 2006). Today, famine relief due to climate extremes is a regular feature in some parts of the arid and semi-arid counties such as Machakos, Laikipia, Turkana and Isiolo Counties.

The effects of droughts and floods have been devastating in Kenya (Table 1). Whereas floods inundates large parts of arable land destroying crops, killing livestock and destroying property, droughts cause deficiency in rainfall leading to decline in water levels affecting agricultural activities. The worst drought in the last one hundred years occurred in 1999-2001 killing approximately 60-70\% of livestock in the arid and semi-arid areas, caused massive crop failures, drying up of water resources, severe environmental degradation and loss of goods and services. Maize yields dropped from 2.5 to 0.5 tonnes/ Ha in Narok County while Kajiado County registered livestock mortality of more than $50 \%$ for cattle and $20 \%$ for shoats. Some individual pastoralists lost their entire herds. In total, about US \$ 340 million was spent in providing humanitarian assistance to the 4.5 million people affected by this drought (UNEP and GoK, 2006). The 1983-84 drought severely affected both pastoralists and crop farmers. Maize and wheat yields dropped by $50 \%$ and $70 \%$ respectively, potato production dropped by more than $70 \%$ while pastoralists lost up to $70 \%$ of their livestock prompting the importation of the yellow maize by the Kenya Government (Cohen and Lewis, 1987). In the arid Wajir, West Pokot and Mandera Counties, the 1991-92 extreme drought led to $100 \%$ loss of livestock by about $70 \%$ of the pastoralists. Maize production in Baringo County decreased by 88\% during the 1988-92 drought (Ngaira, 2005; Ngaira, 1999). Northeastern parts of Kenya bore the burden of the 2005-06 drought where 30-40\% (and up to 70\% in some communities) of livestock was lost. Pressure on resources caused not only mass migration but triggered conflicts and destitution (Grünewald et al, 2006). The 2011 drought caused a humanitarian crisis in the country forcing the government to declare it a national disaster. By May 2011, about 3.2 million people were in dire need of relief assistance while the malnutrition rate had reached an emergency level in arid and semi-arid areas. By July 2011, the humanitarian crisis in the Kenya's arid regions led to what was dabbed as "Horn of Africa Drought Crisis" (KRCS, 2012). 


\begin{tabular}{|c|c|c|c|}
\hline Year $(\mathbf{s})$ & Disaster type & Area of occurrence & Impacts \\
\hline \multirow[t]{2}{*}{2012} & Floods & Nyanza/Western & $\begin{array}{l}84 \text { people killed, } 30,000 \text { displaced } \\
\text { About } 280,000 \text { people affected countrywide }\end{array}$ \\
\hline & Drought & Widespread & $\begin{array}{l}3.75 \text { million people in dire of food by July } \\
2012\end{array}$ \\
\hline 2011 & Drought & $\begin{array}{l}\text { Garissa, Isiolo, Wajir, Mandera, } \\
\text { Mombasa, Marsabit, Nairobi, Turkana, } \\
\text { Samburu and Turkana Counties }\end{array}$ & 4.3 millionpeople were in dire need of food \\
\hline 2010 & Floods & Budalangi, Tana river, Turkana & 73 killed, 14,585 people affected \\
\hline \multirow[t]{2}{*}{2009} & Droughts & Widespread & $\begin{array}{l}70-90 \% \text { loss of livestock by Maasai } \\
\text { pastoralists }\end{array}$ \\
\hline & Floods & & \\
\hline \multirow[t]{2}{*}{2008} & Floods & $\begin{array}{l}\text { Rift valley, Kitale, Transzoia, Makueni, } \\
\text { Mwala/Kibwezi, Bundalangi }\end{array}$ & 24 people killedwiith 2396 affected \\
\hline & Mudslides & Pokot central & 11 people killed \\
\hline 2007-08 & Drought & widespread & $\begin{array}{l}4.4 \text { million people affected, } 2.6 \text { million } \\
\text { people at risk of starvation, up to } 70 \% \text { loss } \\
\text { of livestock in some pastoral communities. }\end{array}$ \\
\hline 2007 & Mudslides & Taita Taveta County & 3 dead \\
\hline \multirow[t]{3}{*}{2006} & Drought & Widespread & $\begin{array}{l}3.5 \text { million in need food by September. } 40 \\
\text { human lives lost and about } 40 \% \text { cattle, } 27 \% \\
\text { sheep and } 17 \% \text { goats lost }\end{array}$ \\
\hline & \multirow[t]{2}{*}{ Floods } & Widespread & 7 deaths, 3,500 people displaced \\
\hline & & Isiolo & 3,000 people displaced \\
\hline \multirow[t]{2}{*}{2005} & Storm & Merti - Isiolo & $\begin{array}{l}4,000 \text { people cut-off between Isiolo and } \\
\text { Merti for } 7 \text { days }\end{array}$ \\
\hline & Drought & Widespread & $\begin{array}{l}2.5 \text { million people close to starvation. } \\
\text { Declared a national disaster }\end{array}$ \\
\hline \multirow[t]{2}{*}{2004} & Drought & Widespread & $\begin{array}{l}\text { About } 3 \text { million people in need of relief aid } \\
\text { for } 8 \text { months to March } 2005\end{array}$ \\
\hline & $\begin{array}{l}\text { Floods/ Land } \\
\text { Slides }\end{array}$ & Nyeri/Othaya Kihuri & 5 people dead \\
\hline 2003 & Floods & Nyanza/Westen, Tana River Basin & 60,000 people affected by severe floods \\
\hline \multirow[t]{2}{*}{2002} & Landslides & Meru Central, Murang'a, Nandi & 2,000 affected \\
\hline & Floods & Nyanza, Busia, Tana River Basin & 150,000 affected \\
\hline $1999-2001$ & Drought & Widespread & 4.4 million people affected \\
\hline $1997-98$ & El Nino Flood & Widespread & 1.5million people affected \\
\hline $1995 / 96$ & Drought & Widespread & $\begin{array}{l}2 \text { million people affected. Declared a } \\
\text { national disaster }\end{array}$ \\
\hline $1991-92$ & Drought & $\begin{array}{l}\text { Arid and Semi-Arid Districts of North } \\
\text { Eastern, Rift Valley, Eastern and Coast } \\
\text { Provinces }\end{array}$ & 1.5 million people affected \\
\hline 1985 & Floods & Nyanza/Western & 10,000 people affected \\
\hline $1983-84$ & Drought & Widespread & 200,000 people affected \\
\hline 1982 & Flood & Nyanza & 4,000 people affected \\
\hline 1980 & Drought & Widespread & 40,000 people affected \\
\hline
\end{tabular}

Table 1: Recent hydrometeorological disasters and their impacts in Kenya

Floods are the most common climatic disaster in Kenya and the leading hydro-meteorological disaster in East Africa. The prevalence rates in Kenya stands at $27 \%$ and affects $5 \%$ of all the population affected by disasters (Otiende, 2009). The most affected areas are the low lying areas of the country located in Kenya's five drainage basins with Lake Victoria Basin being the most affected. Bunyala sub-county is located within this basin and experiences perennial floods from March to May every year and September to October. By and large, most floods in Kenya occur immediately after the droughts causing devastating impacts. In the last two decades, major floods have occurred in 1997-98, 2002, 2003, 2006, 2008, 2010 and 2012. The 1997-98 and 2003 floods were declared as national disasters. During the first quarter of 2010, the raging flash floods claimed the lives of 73 people and 1,864 livestock countrywide. Over 3,375 households were displaced affecting 14,585 people. In addition, at least 16 bridges were destroyed in Rift Valley province (Reliefweb, 2010). Flash floods caused by the 2012 long rains killed 84 people while displacing about 30,000 by June. The total number of people affected was over 280,000 (Relifweb, 2012). The size of the magnitude and the frequency of occurrence of the hazardous processes are key factors in determining the amount of damage caused by a disaster. It is against this background that the current study sought to examine the impact of extreme climatic events on economic development in Kenya. 


\section{Objectives of the study}

The study sought to examine drought and flood characteristics and their associated impacts on the major economic activities in Laikipia North and Bunyala sub-counties of Kenya. Specifically the study aimed at:

(i) Establishing drought and flood characteristics in Laikipia North and Bunyala sub-counties respectively

(ii) Examining the impacts of droughts and floods on economic activitiesin the study areas

\section{Study area and methodology}

Two different study areas were used: Laikipia North and Bunyala sub-counties. Laikipia sub-county is located in central parts of Kenya between latitudes $0^{0} 15^{\prime}$ and $0^{0} 33^{\prime}$ North and longitudes $36^{\circ} 50^{\prime}$ and $37^{\circ} 24^{\prime}$ East (Figure 1). The climate is semi-arid with mean annual rainfall of $508 \mathrm{~mm}$ and mean annual temperatures range of $18^{\circ} \mathrm{C}$ and $20^{\circ} \mathrm{C}$. The sub-county is primarily a rangeland suitable for pastoralism. Pastoralists entirely rely on rainfall perfomance for pasture and water for their livestock. Bunyala sub-county where mixed farming is the main source of livelihood in Bunyala is located in western Kenya between latitudes $0^{\circ} 00^{\prime}$ and $0^{0} 33^{\prime}$ South and longitudes $33^{\circ} 95^{\prime}$ and $34^{\circ} 07^{\prime}$ East. It lies in the swampy tracts of River Nzoia that are prone to frequent flooding. The sub-county experiences seasonal flooding due to overtopping of Rivers Nzoia and Yala. River Nzoia divides the sub-county into two parts: the northern and the southern parts. The high river discharges that cause flooding in the area emanate from the high annual rainfall in the upper catchment areas that range from 1600$2000 \mathrm{~mm}$ (Otiende, 2009). Dykes were constructed on both sided of River Nzoia in the last 16 kilometres from Lake Victoria to control flooding.

Annual rainfall amounts were used to establish drought events and their characteristics. Rainfall data was obtained from Mpala Ranch rainfall station in Laikipia North sub-county. Any given year whose annual rainfall was below the long term mean of $508 \mathrm{~mm}$ was considered a drought year. Drought intensity was measured by the departure of the rainfall from the long-term mean and was expressed as a percentage as shown below.

$$
\begin{aligned}
\mathrm{DI}=\frac{\mathrm{x}-\overline{\mathrm{x}}}{\overline{\mathrm{x}}} \times 100 \% & \\
\text { Where } \mathrm{DI} & =\text { Drought intensity } \\
\mathrm{x} & =\text { Annual rainfall for a given year } \\
- & \\
x & =\text { Mean annual rainfall for the study period (1975-2005) }
\end{aligned}
$$

The severity of the drought was analyzed using Standardized Precipitation Index (SPI) which was computed using the equation below. Four categories of drought severity were identified: mild (0 to -0.99$)$, moderate (-1.00 to -1.49$)$, severe $(-1.50$ to -2.00$)$ and extreme $(<-2.00)$

$$
\begin{aligned}
& S P I=\frac{x-\bar{x}}{\sigma} \\
& \text { Where: } \sigma=\text { Standard deviation } \\
& x=\text { Annual rainfall for a given year } \\
& \bar{x}=\text { Mean annual rainfall for } 31 \text { years (1975-2005) }
\end{aligned}
$$

For estimation of flood magnitude, water levels (in Metres) were obtained from River Gauging Station (RGS) 1EF01 located at Ruambwa bridge in Bunyala sub-county. This is the last RGS of River Nzoia downstream. For frequency analysis, the study used annual duration series which considers the highest river discharge for every year. River discharge equation was used in computing water levels into discharges (in metres/second). The following equation was used.

$\mathrm{Q}_{1}=\mathrm{A} * \mathrm{H}^{\mathrm{B}} \quad \mathrm{H}_{\mathrm{L}} \leq \mathrm{H} \leq \mathrm{H}_{\mathrm{H}}$

Where;

$\mathrm{Q}_{1}=$ River discharge velocity $\left(\mathrm{m}^{3} / \mathrm{s}\right)$

$\mathrm{A}=$ Constant $\mathrm{A}$

$\mathrm{B}=$ Constant $\mathrm{B}$ 


\section{$\mathrm{H}=$ Water levels \\ $\mathrm{H}_{\mathrm{L}}=$ Lowest water levels \\ $\mathrm{H}_{\mathrm{H}}=$ Highest water levels}

From the equation any discharge of 245.70 cubic metres/ second and above at RGS 1EF01 was considered as a high flow and would cause flooding in the sub-county. The frequency of reoccurrence for a given flood magnitude was computed using the recurrence interval equation as shown below.

Where, $\mathrm{T}=$ recurrence interval

$$
T=\frac{n+1}{r}
$$

$\mathrm{n}=$ number of years for the period studied

$r=$ rank order of flood magnitudes from the highest to the least

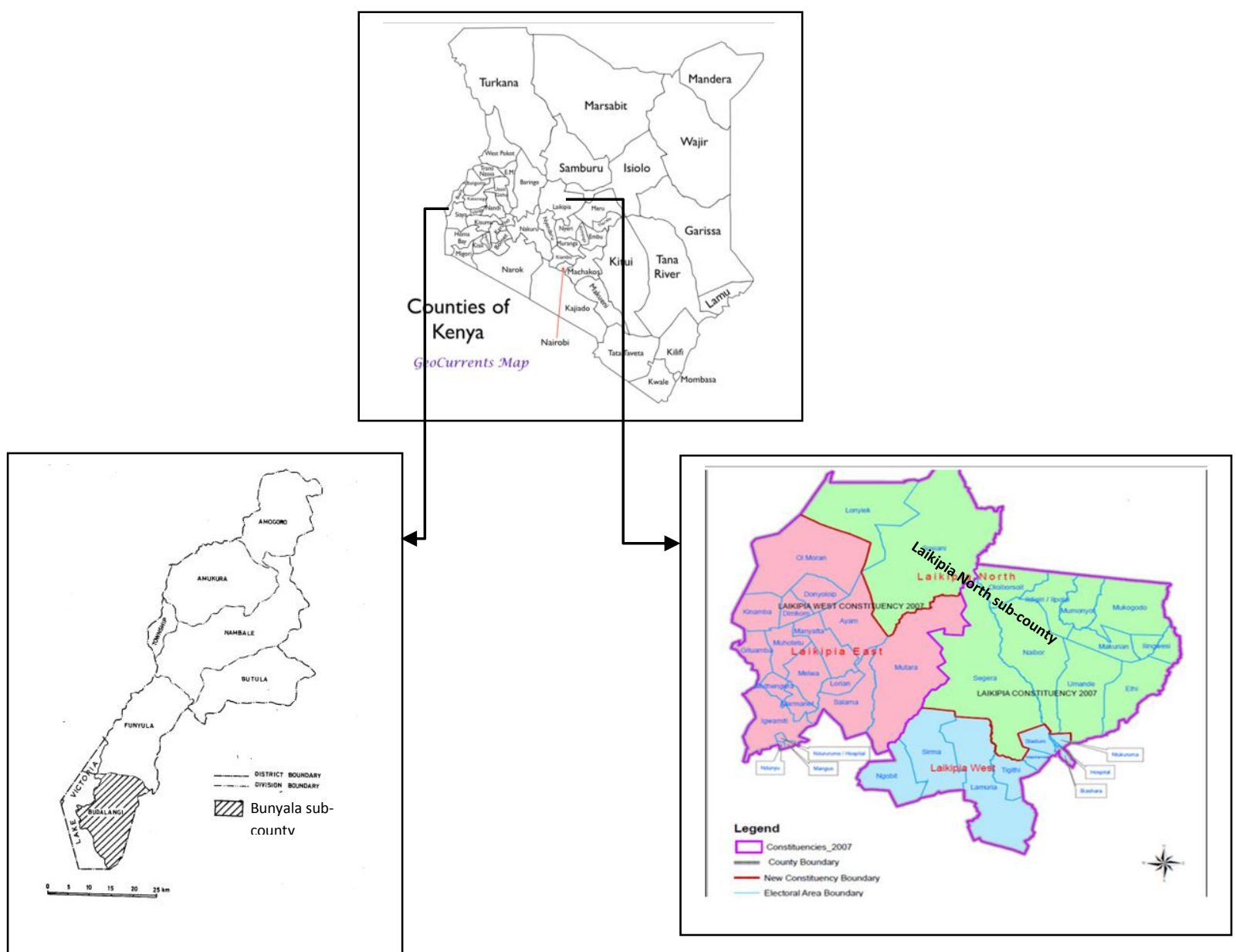

Figure 1: Location of the study areas

\section{Results And Discussion}

\section{Droughts and their impacts in Laikipia North sub-county}

The climate of Laikipia North sub-county is influenced by the dry northeast monsoon from the Arabian continent and the Harmattan air mass from the Sahara desert (Ojany and Ogendo, 1973) and the lee effect of Mount Kenya. These factors cause dry climatic conditions that pose major challenges to economic development in the area. For a period of 38 years, 1975 and 2012, the sub-county experienced 22 years of drought, i.e. in 1976, 1980, 1982-85, 1987, 1991-96, 1999-2000, 2002, 2005, 2007-2008 and 2009-2011. More than 75\% of the droughts that occurred in the sub-county were of large spatial extent i.e. they occurred concurrently with droughts in other parts of Kenya. Such droughts included: the 1980, 1982, 1983, 1984, 1985, 1987, 1991, 1992, 1993, 1994, 1996, 1999, 2000 2005, 2006, 2009 and 2011 droughts. The concurrence of such droughts has been associated with the El Niño Southern Oscillation (ENSO) phenomenon (Wang'ati, 1996; WWF, 2006) which cause below normal rainfall in Kenya (Anyamba, et al. 2001). The severity of the impacts caused by such droughts has in many occasions prompted the Government of Kenya to declare them as national disasters. 
Droughts which have been declared as national disasters include the 1984, 1991-92, 1994, 1999-2000, 2005, 2009-2010 and 2011.

About $60-70 \%$ of the 1980, 1990 and 2000 decades were characterized by drought events, all of varying characteristics. The duration varied from 1 to 6 years with about $70.6 \%$ of the droughts occurring in runs of 2-6 years. The 1991-96 and 2007-2012 droughts were the longest each lasting for six years. Frequency of occurrence of droughts in the sub-county increased from 6 years in every 10 in the 1980 decade to 7 in the 1990 and 2000 decades. Similarly, the intensity of the droughts showed an increasing trend (Table 2). In the 1980 decade, rainfall amounts during the drought years were $26.2 \%$ below the 1975-2005 mean. The intensity increased to $29.6 \%$ and $34.6 \%$ in 1990 and 2000 decades respectively. The increasing severity and frequency of drought occurrence was an indication that the climate of the sub-county was getting drier reflecting the marked changes in the climate of the arid northern Kenya. This observation concurs with Howden (2009) who notes that the climate of northern Kenya is getting drier.

Table 2: Increasing drought intensity in Laikipia North sub-county

\begin{tabular}{|c|c|c|}
\hline $\begin{array}{l}\text { Drought } \\
\text { Year }\end{array}$ & $\begin{array}{l}\text { Total annual } \\
\text { rainfall (mm) }\end{array}$ & Mean annual rainfall during drought years $(\mathrm{mm})$ \\
\hline 1980 & 297.2 & \multirow{6}{*}{$374.9 \mathrm{~mm}$ (26.2\%below the mean) } \\
\hline 1982 & 476.6 & \\
\hline 1983 & 466.8 & \\
\hline 1984 & 188.5 & \\
\hline 1985 & 448.1 & \\
\hline 1987 & 371.9 & \\
\hline 1991 & 214.6 & \multirow{7}{*}{$357.7 \mathrm{~mm}$ (29.6\%below the mean) } \\
\hline 1992 & 360.7 & \\
\hline 1993 & 359.4 & \\
\hline 1994 & 502.9 & \\
\hline 1995 & 439.4 & \\
\hline 1996 & 184.2 & \\
\hline 1999 & 443 & \\
\hline 2000 & 186.9 & \multirow{3}{*}{$\quad 332.1 \mathrm{~mm}$ (34.6\%below the mean) } \\
\hline 2002 & 420.2 & \\
\hline 2005 & 389.3 & \\
\hline
\end{tabular}

The effects of droughts on economic activities were dependent on their magnitudes, i.e. intensity, severity and duration. Severe to extreme droughts had more pronounced effects on the pastoral economy compared to mild and moderate droughts. Pastoralists in the sub-county experienced an inverse relationship between drought severity and livestock prices and positive relationships with livestock losses. Livestock losses ranged from 425 during the year 2002 mild drought which had a severity index of -0.58 to 26,500 during the 1991-96 extreme drought which had a cumulative severity index of -6.49 (Table 3). The 1991-96 extreme drought caused massive loss of livestock was thus referred to as olrameiolakiralokidongoi (the drought that killed everything) by the pastoralists. Similarly, the 1983-85 extreme drought caused hunger and starvation not only in the sub-county but countrywide prompting the importation of the yellow maize by the Kenya Government. A strong positive correlation coefficient of $+0.88(\mathrm{P}=0.05)$ was established between livestock loss and drought severity. Estimation through Coefficient of Determination indicated that up to $77 \%$ of livestock losses could be directly attributed to increase in drought severity.

Table 3: Number of livestock lost during droughts of varying severities

\begin{tabular}{l|c|c}
\hline Drought event & Drought Index & Number of livestock lost \\
\hline $1983-85$ & -2.76 & 19,072 \\
1987 & -1.00 & 10,945 \\
$1991-96$ & -6.49 & 26,500 \\
$1999-2000$ & -2.54 & 18730 \\
2002 & -0.58 & 425 \\
2005 & -0.78 & 530 \\
\hline
\end{tabular}


Livestock prices varied depending on the availability of pasture and water. High prices were fetched during wet periods but deteriorated with increasing drought severity. Inadequate pasture and lack of water during droughts led to increased livestock diseases, poor body conditions and low meat and milk productivity causing low demand for livestock and livestock products. Cattle prices dropped from Kenya Shillings (KShs) 11,000 during the 1992 mild drought to KShs 6,000 during the 1996 extreme drought while sheep and goats (shoats) prices dropped from KShs 1,425 to KShs 600 over the same period (Table 4). Negative correlation coefficients of -0.83 for cattle and -0.63 for shoats $(\mathrm{P}=0.05)$ were established. About $68.9 \%$ and $39.7 \%$ decline in cattle and shoat prices were directly associated with increase in drought severity.

Table 4: Livestock prices during drought of varying severities

\begin{tabular}{|l|c|c|c|}
\hline Drought Year & Drought Index & $\begin{array}{l}\text { Mean cattle } \\
\text { prices (KShs) }\end{array}$ & $\begin{array}{l}\text { Mean shoat } \\
\text { prices (KShs) }\end{array}$ \\
\hline 1987 & -1.00 & 11500 & 1300 \\
\hline 1991 & -1.93 & 8000 & 750 \\
\hline 1992 & -0.97 & 11000 & 1425 \\
\hline 1993 & -0.98 & 10500 & 1350 \\
\hline 1994 & -0.03 & 10300 & 1245 \\
\hline 1995 & -0.45 & 10200 & 1125 \\
\hline 1996 & -2.13 & 6000 & 600 \\
\hline 1999 & -0.43 & 12600 & 1545 \\
\hline 2000 & -2.11 & 7500 & 825 \\
\hline 2002 & -0.58 & 11633 & 1515 \\
\hline 2005 & -0.78 & 11350 & 1500 \\
\hline
\end{tabular}

During droughts events, shortage of water and pasture sparked conflicts amongst the Maasai pastoralists living in Laikipia North sub-county and the Samburu and the Kalenjin pastoralists from the neighbouring Samburu and Baringo Counties as they scrambled for these meager resources. The aftermath was loss of livestock, human displacement and loss of property and poor market prices. Pastoralists dependent on each other for livestock market and therefore peaceful coexistence remained critical in determining market prices. With increasing drought frequency and severity the future of the pastoral economy in the area looks blink.

\section{Floods and their effects in Bunyala sub-county}

The low lying areas of Bunyala sub-county were affected by floods every rainy season. Floods occurred as a result of overtopping of River Nzoia and increased water levels in Yala swamps, the latter affecting the southernmost parts of the sub-county. Being located on the flood plains of River Nzoia, high river discharge triggered by heavy rainfall in the upper catchment areas (Elgon Downs, Kitale, Eldoret and Bungoma regions) of the river caused flooding in the sub-county. According to Pinter (2010) land-use change, climate shifts, and engineering activities and structures along the rivers are main causes of increase in frequency, duration and magnitude of the floods. This is true for Bunyala sub-county as increased river discharge has been caused by conversion of forested areas into agricultural land, poor engineering works of the dykes which have contributed to frequent breakages of the dykes at the meandering points and increased rainfall intensity in the upper catchment areas of Rivers Nzoia and Yala (Action Aid, 2003).

Floods in the area show seasonality of events as they follow rainfall seasons in the country. Highest flood peaks occurring in May and September which coincides with the long and the short rains respectively. Like droughts, flood characteristics differed from one event to the other in terms of magnitude and duration. Between 1990 and 2003 at RGS 1EF01, River Nzoia recorded a mean annual flood magnitude of $363.81 \mathrm{~m}^{3} / \mathrm{s}$ with a recurrence interval of 2.33 years. The highest flood magnitude occurred in $2003\left(493.60 \mathrm{~m}^{3} / \mathrm{s}\right)$. Other high flood magnitudes occurred in $1992\left(415.01 \mathrm{~m}^{3} / \mathrm{s}\right), 1997\left(401.08 \mathrm{~m}^{3} / \mathrm{s}\right), 2002\left(396.13 \mathrm{~m}^{3} / \mathrm{s}\right)$ and 1998 $\left(391.17 \mathrm{~m}^{3} / \mathrm{s}\right)$. Such flood of high magnitude were less frequent and had recurrent intervals of 15, 7.5, 5, 3.75 and 3 years respectively. Low magnitude floods were more frequent. For instance, the year 2000 flood (296.76 $\mathrm{m}^{3} / \mathrm{s}$ ) had a recurrence interval of 1.07 years (Figure 2). Nevertheless, linear trend analysis indicated a gradual increase in flood magnitude in the sub-county (Figure 3). 


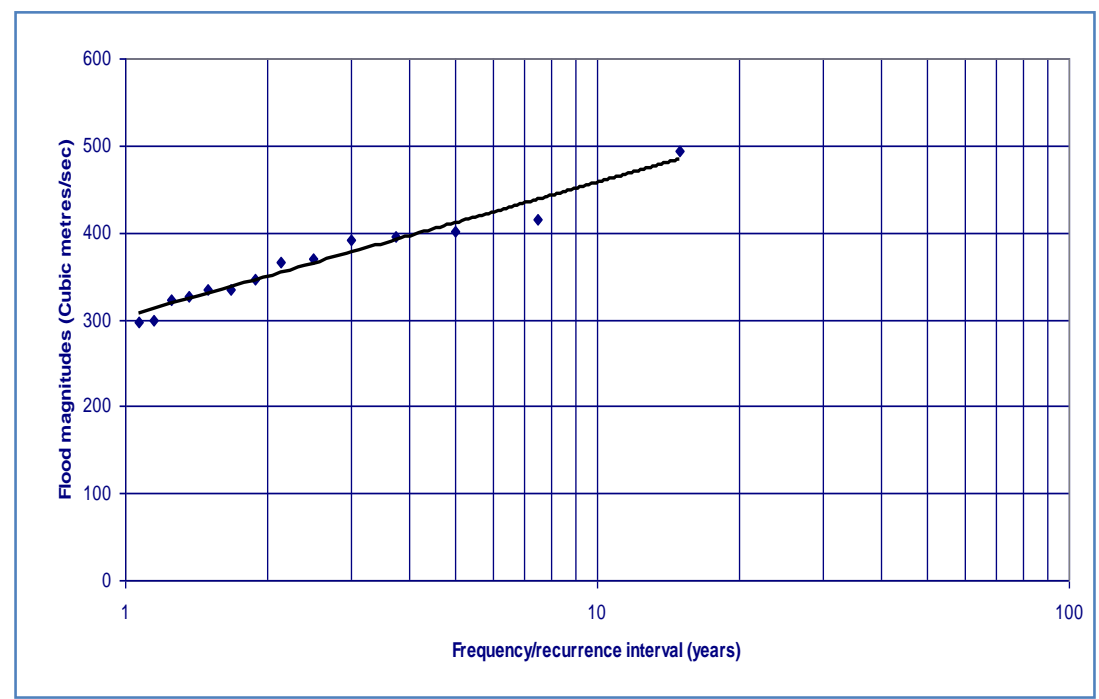

Figure 2: Flood recurrence intervals (1990-2003)

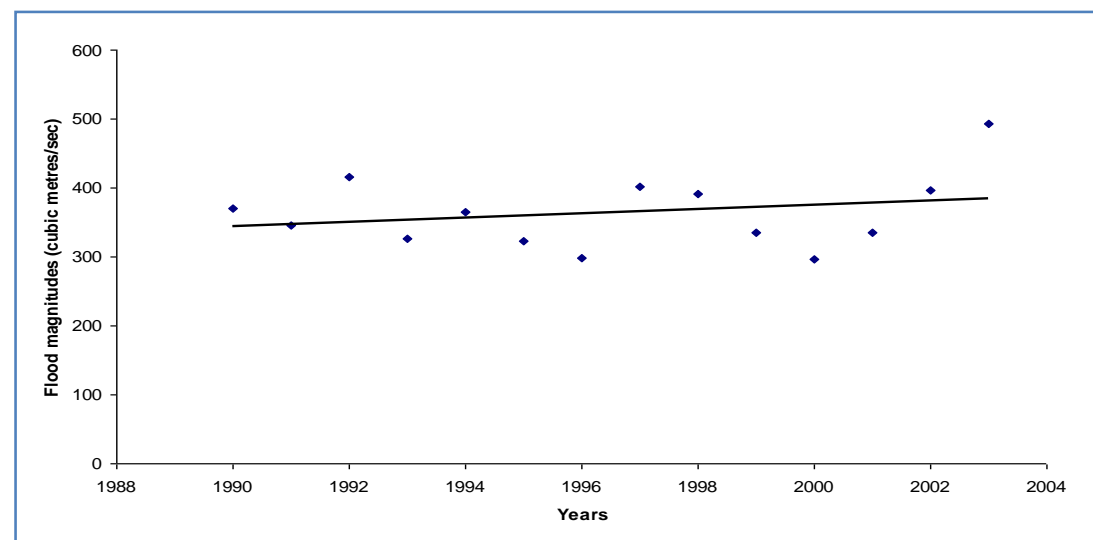

Figure 3: Flood magnitude trend at RGS 1EF01 (1990-2003)

The length of time the floodwater takes on the farmlands defines the duration of the floods. Flood duration in Bunyala, like any other areas, dependent up on the magnitude of the flood, the number of days with high flows, land topography and soil type. Longer flood periods occurred during high flood magnitudes and lessened with decreasing magnitude. The high magnitude flood of year $2003\left(493 \mathrm{~m}^{3} / \mathrm{s}\right)$ left parts of sub-county inundated for up to 153 days.

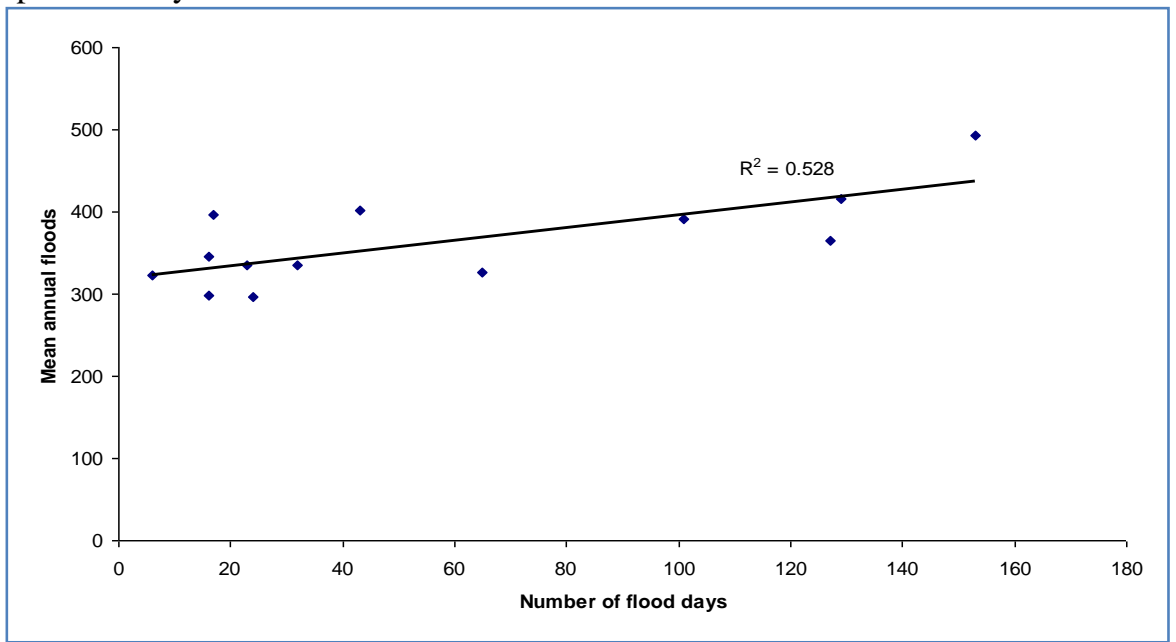

Figure 4: Flood magnitudes and number of flood days (1990-2003)

Despite the fact that the occurrence of a particular flood magnitude can be predicted with reasonable accuracy, Otiende (2009) observes that the impact of floods on Kenya's economic development is increasing 
and now a major concern for the government. Destruction of property and infrastructure alongside the displacement of people caused by floods pose the major threat to economic development in Bunyala sub-county. The consequences had been reduction in family income, decline in production in agricultural sector, business enterprises, inflation and unemployment. Relief and reconstruction efforts often compete with development programs for available funds. Like droughts, the amount of flood damage depended on the size of the magnitude. Analysis of maize, sorghum, beans and cassava yields revealed negative correlations between the yields and flood magnitudes. Crop yields decreased with increase in flood magnitude. Strong negative correlation coefficient of $\quad-0.8(\mathrm{P}=0.05)$ was established for maize crop. The high vulnerability to flooding of was caused by the inability of maize crop to withstand water logged soils and the longer growing periods. Weak negative correlations coefficients of $-0.3,-0.2$ and -0.1 were established for sorghum, beans and cassava respectively. Bean crops were less affected by floods since they are quick maturing crops. Together with the early planting practice (early March), bean crops escaped flooding which occurred in April and peaked in May. Sorghum withstands waterlogged soils thus more resistant to floods. However, as floods magnitude increased so did the effects on the sorghum yields.

Effects of floods on livestock were minimal due to the ability of animals to move on safer grounds. However, the number of livestock loss increased as flood magnitude increased. Increase in pests and diseases was rampant during flooding periods as floods provided conducive environment for multiplication of liver flukes and breeding of tsetse flies. As a consequent, the rate of liver fluke and Trypanasomiasis infections escalated during flooding periods. The situation hampered the development of daily cattle industry in the area (GOK, 2002). Other challenges posed by floods included drowning of animals, shortage of pasture due to inundation and lack of market for livestock and livestock products. For instance, during the 1997-98 floods a pig was sold at KShs 500 down from KShs1000 in 1996. The number of cattle and sheep lost was higher compared to that of goats and chicken. Being grazers, inundation of pastures led to inadequate foliage and increase in liver fluke infections. Whereas cattle and sheep numbers showed negative relationships $(r=-0.3$ and -0.2 respectively), goat and chicken showed positive relationships $(r=+0.2)$ with flood magnitudes. Time series analysis showed a gradual increase in the number of chicken and goats in the sub-county (Table 5). Low capital investment required in the purchase and rearing of chicken after the floods led to increase in their numbers over time. Similarly, the adaptability of goats to harsh dry climatic conditions on the safer higher ground and the browsing habit led to increase in their numbers.

Table 5: Number of livestock in Bunyala sub-county between 1991 and 2003 (GoK, 2004)

\begin{tabular}{|l|l|l|l|l|l|}
\hline Year & \multirow{2}{*}{$\begin{array}{c}\text { Flood magnitude } \\
\left(\mathbf{m}^{3} / \mathbf{s}\right)\end{array}$} & \multicolumn{4}{|c|}{ Number of animals } \\
\cline { 3 - 6 } & & Cattle & Sheep & Goats & Chicken \\
\hline 1991 & 346.00 & 21,840 & 7,660 & 12,776 & 39,230 \\
\hline 1992 & 415.01 & 25,380 & 7,780 & 13,345 & 44,375 \\
\hline 1993 & 326.58 & 26,800 & 7,890 & 14,050 & 66,585 \\
\hline 1994 & 365.56 & 30,380 & 8,200 & 13,400 & 52,720 \\
\hline 1995 & 322.71 & 30,500 & 8,850 & 11,000 & 37,000 \\
\hline 1996 & 298.67 & 30,000 & 9,300 & 11,600 & 25,140 \\
\hline 1997 & 401.08 & 26,000 & 12,000 & 18,000 & 90,000 \\
\hline 1998 & 391.17 & 22,000 & 6,000 & 15,000 & 56,000 \\
\hline 1999 & 334.33 & 17,350 & 4,500 & 13,400 & 68,940 \\
\hline 2000 & 296.76 & 13,400 & 3,400 & 10,030 & 82,640 \\
\hline 2001 & 335.30 & 9,823 & 2,704 & 9,483 & 77,941 \\
\hline 2002 & 396.13 & 10,321 & 3,248 & 12,572 & 79,685 \\
\hline 2003 & 493.60 & 9,400 & 2,840 & 10,200 & 68,000 \\
\hline
\end{tabular}

Fishing, which was the second major income earning activity in the sub-county, was equally affected by floods. Fish production declined with increasing flood magnitude. Minimum catch were common during flooding periods due to the following: (i) migration of fish from littoral to pelagic waters that was occasioned by high contamination of littoral waters by farm chemicals and increased turbidity and, (ii) submersion of the main fish landing beaches which included Musoma, Mukoma and Osieko by the rising waters of Yala Swamp. This forced some fishermen to stop their fishing activities and engage in boat transport (Plate 1). This observation confirms Grove (1989) who notes that year-to-year variations in fish production in Africa are dependent on the size of the seasonal floods. A weak negative correlation of -0.2 was established between fish production and flood magnitudes. Dilapidated road conditions during floods hindered buyers from accessing the fish landing 
beaches causing low demand for the fish and consequently affecting fish prices. As floods increased in magnitude so did the road became impassable in turn affecting the prices. For instance, a kilogram of Nile perch dropped from KShs 60 in 2002 to KShs 20 during the year 2003 floods.

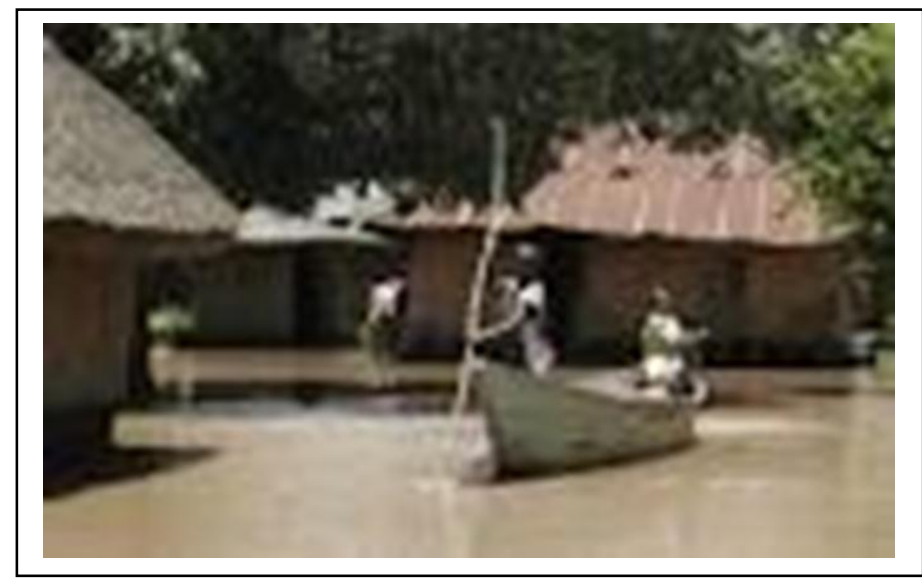

Plate 1: People ferried using boats from their homestead to higher grounds.

\section{Coping strategies against droughts and floods}

To survive the hydrometeorological disasters, the inhabitants of the study area had evolved some risk reduction measure. Most of the survival strategies employed were short-term and were geared towards coping with the immediate disaster. These included:

(i) Increasing the number of sheep and goats (shoats). Livestock farmers increased the number of shoats because of their resilience to drought. Whilst in Laikipia North sub-county pastoralists increased both the number of sheep and goats, livestock farmers in Bunyala sub-county increased the number of goats and chicken.

(ii) Charcoal burning and selling of firewood

(iii) Brick making and sand harvesting

(iv) Out migration

(v) Illegal logging from Mukogodo and Sisenye forest reserves for Laikipia north and Bunyala sub-counties respectively.

Unfortunately, some of the strategies such as increasing the number of shoats, charcoal burning, illegal logging, brick making and sand harvesting were damaging to the environment. For instance, the eating habits of shoats degrade vegetation cover very quickly leaving the soils bare, a prerequisite for soil erosion. Similarly, felling trees for timber/ poles and charcoal burning depleted the forest cover. Trees sequesters carbon dioxide hence plays a major role in climate change mitigation. Frequent out migration disturbed agricultural activities, which was the main source of income for the inhabitants. Farmers depended on relief aid and food handouts for existence. The consequence of environmental degradation in the study areas has been poor agricultural production and thus a vicious cycle of poverty and economic underdevelopment.

\section{Conclusion and recommendations}

Rainfall performance is critical for sustained growth of the economy of Kenya which is agri-based. Extreme climatic events associated with droughts and floods pose the greatest challenge to economic development since over $80 \%$ of the Kenyan populace depends on agriculture as their livelihood source. The destruction of the economic base by droughts and floods exacerbated poverty levels especially where agriculture was marginal. Farmers experienced massive livestock mortality, low livestock and crop production, poor crop and livestock prices and human displacement. The amount of damage on the economy was dependent on the magnitude and the frequency of occurrence of the disaster with an inverse relationship. That is, the economic growth declined with increasing disaster magnitude and frequency. To cope with economic hardships, inhabitants turned to exploit their immediate environment causing further degradation hence accentuating the magnitude and frequency of the disaster. The consequence has been increased frequency of recurrence and the severity of drought and flood events and hence a vicious cycle of poverty.

Building resilience to the affected community after any disaster is important for continued economic development. The amount of resources for building resilience varies considerably depending on the magnitude of the disaster. Lower magnitude disasters require lesser resources compared to high magnitude, which are in most cases not sustainable. The study calls for thorough understanding of the magnitude of the disasters and the associated impacts on socioeconomic activities to enable zoning of risk areas. This will allow proper planning of 
relief measures and emergency assistance and establishment of disaster mitigation measures. Early warning systems should be developed and implemented to reduce the losses accruing for the disasters while at the same time communities should be encouraged to use indigenous knowledge to cope the disasters as this is not only cost effective but also sustainable.

\section{Reference}

[1]. Action Aid (2012) East Africa drought. Available online at: http://www.actionaid.org/what-we-do/emergencies-conflict/currentemergencies/east-africa-drought

[2]. Alleyne, R. (2009) Catastrophic Droughts in Africa are the Norm, Claim Scientists. In The Telegraph. Available at:http://www.telegraph.co.uk/earth/ environment/climatechange/5165168/

[3]. Anyamba, A. Linthicum, K. J. and Tucker, C. J. (2001) Climate-disease connections: Rift Valley Fever in Kenya. Cad. Saúde Pública vol.17 suppl. Rio de Janeiro 2001. doi: 10.1590/S0102-311X2001000700022

[4]. Ayoti O. (2008) Kenya has no policy on drought, Minister confesses. Available: http://desertificationwordpress.Com/2008/05/29/kenya-has-no-policy-on-drought-google-africa-sciencenews-service/

[5]. Clarke R. (1991) Water: The international crisis. Earthscan Publication, London.

[6]. Cohen, J. M. and Lewis, D. B. (1987) Role of government in combating food shortage: Lessons from Kenya 1984-85. In Glantz, M. H. (ed) Drought and hunger in Africa. Cambridge University Press, Cambridge. Pp 269-296.

[7]. Cohen, S. and Miller K.A. (2001) Climate Change 2001: Impacts, Adaptation, and Vulnerability. Contribution of Working Group II to the Third Assessment Report of the Intergovernmental Panel on Climate Change. Cambridge: Cambridge University Press.

[8]. Drought Management Centre (2004) Natural hazards: cause and effects. Disaster management Centre, Wisconsin.

[9]. Farmer, G. and Wigley, T. M. L. (1985) Climate trends for tropical Africa: A research report for the Overseas Development Administration. Climatic research unit. University of East Anglia, Norwich GoK (2002) Busia District Development Plan 20022008. Government printers, Nairobi

[10]. GoK (2009) National policy for disaster management in Kenya. Ministry of State for Special Programmes, Government printers. Nairobi

[11]. Grünewald, F., Robins, K., Odicoh, A. and Nicholson, N. (2009) Kenya. RTE mission final report

[12]. Houghton J. (1997) Global Warming: The Complete Briefing. Cambridge University Press, Cambridge.

[13]. Howden, D. (2009) The great drought in East Africa; No rainfall for three years. Available at: http://www.infiniteunknown.net/2009/10/03/the-great-drought-in-east-africa-no-rainfall-for-three-years/ gov/fews/africa/index.php

[14]. http://www.chiefscientist.qld.gov.au/publications/understanding-floods/consequences.aspx (2013) What are the consequences of floods? Downloaded on 15/4/2013.

[15]. IRIN (2013) Kenya: Early warning volunteers try to prevent flood misery. Retrieved fromhttp://www.irinnews.org/report/95351/KENYA-Early-warning-volunteers-try-to-prevent-flood-misery

[16]. KRCS (2012) DROUGHT 2011: How Kenya responded. https://www.kenyaredcross.org/PDF/K4K/Drought\%202011\%20:\%20How\%20Kenya\%20Responded.pdf

[17]. Ojany, R. B. and Ogendo, F. B. (1973) Kenya: A Study in physical and human Geography.Longman group, Nairobi.

[18]. Otiende, B. (2009) The Economic impacts of climate change in Kenya: Riparian flood impacts and cost of adaptation. Available online at: http://static.weadapt.org/knowledge-base/files/758/4e25a4b8c8bf61C-kenya-riparian-floods-case-study.pdf

[19]. Ngaira, J. K. (1999) Environmental impact of rainfall variability in the semi arid areas: a case study of Baringo district, Kenya. Unpublished PhD thesis, Moi University.

[20]. Ngaira, J. K. (2004) Basic facts in contemporary climatology. Lake publishers and enterprises, Kisumu.

[21]. Ngaira, J. K. (2005) Hydrometeorological disasters and their impact on development: The Kenya experience. In Maseno journal of education, arts and sciences. Vol 5 no 1, Maseno.

[22]. Pinter, N. (2010) Fluvial geomorphology and flood hydrology. Southern Illinois University Carbondale.

[23]. Reliefweb (2012) Retrieved from:http://reliefweb.int/disaster/ff-2012-000062-ken

[24]. Reliefweb (2010) Floods affect thousands in Kenya. Retrieved from: http://reliefweb.int/report/kenya/floods-affect-thousandskenya-06-apr-2010

[25]. UNEP \& GOK (2006). Kenya drought: Impacts on agriculture, livestock and wildlife. UNEP, Nairobi.

[26]. Wang'ati, F. J. (1996) Impact of climate variation and sustainable development in the Sudano-Sahelian region. In Ribot, J. C., Magalhaes, A. R. and Panagides, S. S. (eds) Climate variability, climate change and social vulnerability in the Tropics. Cambridge University Press, Cambridge pg 71-91.

[27]. Wani, S. P., Sreedevi, T. K., Rockstrom, J. and Ramakrishna, Y. S. (2009) Rainfed agriculture: past trends and future prospects. In Wani, S. P., Rockstrom, J. and Oweis, T. (eds) Rainfed agriculture: Unlocking the potential. CAB international, London, pp 1-36

[28]. WWF (2006) Climate change impacts on east Africa: A review of the scientific literature. WorldWide Fund (WWF), Switzerland 